Tourism ResearchJournal

E-ISSN: 2598-9839

2020, Vol. 4 No. 2

\title{
Do Facilities Affect Tourists' Satisfaction at Natural Tourist Attraction? A Case at Tegenungan Waterfall in Bali.
}

\author{
Gede Muna Satya Febriyana ${ }^{1}$, I G.N. Agung Suprastayasa ${ }^{2 *}$, Made \\ Darmiati $^{3}$ \\ 1 Alumnus Politeknik Pariwisata Bali (Bali Tourism Polytechnic) \\ 2,3Politeknik Pariwisata Bali (Bali Tourism Polytechnic) \\ *agung.suprastayasa@ppb.ac.id
}

\begin{abstract}
Research on tourist satisfaction has been a topic of interest for many academicians. This study aimed to examine the effect of tourist facilities on tourist satisfaction at the natural attractions of Tegenungan waterfall, Bali. The sampling method used was accidental sampling with 100 samples collected in 5 days. Analysis of the data used is descriptive analysis and simple linear regression analysis. The results of the study indicate that the tourist facility variable has a significant effect on tourist satisfaction. $\mathrm{T}$ test results show that the tourist facilities $(\mathrm{X})$ significantly affect tourist satisfaction (Y) at the natural attractions of Tegenungan waterfall, Bali. It is expected that the quality of existing tourist facilities can be improved so that it can have a positive impact on the satisfaction of tourists visiting the waterfall.
\end{abstract}

Keywords: tourist facilities, tourist satisfaction, natural tourist attraction, 
Do Facilities Affect Tourists' Satisfaction at Natural Tourist Attraction? A Case at Tegenungan Waterfall in Bali

\section{A. Introduction}

Bali Province is one of the leading provinces in the tourism sector in Indonesia. Based on its history, Bali has a relatively long history in the tourism industry. At the beginning of the development, many obstacles were found in terms of lack of facilities and infrastructure and human resources to support Bali's tourism development. Over time, Bali has now become a popular tourist destination among domesticas well as foreign tourists and this is one of the causes of rapid infrastructure growth and improved tourism facilities.

The number of tourist visits to Bali continues to increase every year. In 2016 there was a growth of foreign tourists to Bali by $23.14 \%$ or by $4,001,835$ tourists. In comparison, the smallest growth occurred in 2018, which amounted to $6.54 \%$ or as many as $6,070,473$ foreign tourists coming to Bali. In addition to foreign tourists, domestic tourists are also increasing every year. The biggest increase occurred in 2016, amounting to $20.91 \%$ from the previous year or by $8,735,633$ tourists. In comparison, the smallest growth occurred in the following year which was $8,735,633$ tourists with a growth percentage of 1.06.

According to Pitana and Diarta (2009), natural resources that can be developed into natural attractions are natural wonders and beauty, diversity of flora and fauna, wildlife life, natural vegetation, ecosystems which have not been touched by humans, recreation comfortable waters, megalithic objects, temperature and humidity. Nature tourism attraction is one of the tourist attractions which is visited by many tourists. One of the attractions of nature tourism which is visited by many tourists in a destination is waterfall. Many tourists are quiteenthusiasticto visit the natural tourism of the waterfall, because besides the attractive and beautiful nature, a waterfall is also very popular among tourists for photo objects as well as selfy. One of the famous waterfalls as a tourist attraction in Bali is Tegenungan waterfall. It can be reached from two sides, the village of Tegenungan and the village of Blangsinga. It is located in the District of Blahbatuh, Gianyar Regency. Both domestic and international tourists usually visit the waterfall.

Many researches have been done on the topic of tourists' satisfaction. Most studies discuss the impact of service quality on the tourists' satisfaction and also loyalty. The contexts vary like restaurant, hotel, airline and tour and travels. Utama, et al. (2011), examined the effect of service quality on customer satisfaction and loyalty of fast food restaurants. Hapsari, et al. (2017) investigated the effect of service quality, customer engagement and some selected marketing constructs on airline passenger loyalty. However, few studies are investigating the impact of tourist facilities on tourist satisfaction, especially in the natural tourist attraction of Tegenungan waterfall. Therefore, this study aimed at investigating such relationship between tourist facilities and tourist satisfaction. 
Do Facilities Affect Tourists' Satisfaction at Natural Tourist Attraction? A Case at Tegenungan Waterfall in Bali

\section{B. Literature Review}

\section{Tourism Facilities}

According to Yoeti (2003: 56) tourism facilities are all facilities whose function is to meet the needs of tourists who stay for a while in the tourist destination they visit, where they can relax and enjoy and participate in activities available in the tourist destination. In addition, Mappisammeng (2001: 39) states that one of the most important things to develop in tourism is facilities (convenience). It is not uncommon for tourists to visit a place or region or country, because they are attracted by the convenient facilities that can be obtained through facilities.

Activities carried out in a tourist attraction will certainly always require tourist facilities and each facility has several components.Here are some parts of the components of tourism facilities according to (Yoeti, 2003: 56): accommodation units, restaurants, bars and cafes, transports at the destination, sports and activities, other facilities, retail outlets, and other services.

Concerning accommodation units, it is required for a tourist attraction to have at least a place to stay located close to the tourist attraction or in the tourist attraction area. In restaurants bars and cafes requires a tourist attraction to have facilities that are small to large scale restaurants, bars or cafes. Transports at the destination as an indicator that illustrates that a tourist attraction has at least vehicle rental or transportation services. Sport and activities are fun activities on tourist attractions, other facilities on tourist attractions such as: a photo and gazebo. Retail outlets on tourist attractions such as: food stalls, money changers, souvenir shops. Other services on tourist attractions such as: information services for tourists and drivers waiting places.

According to Kiswanto (2011: 43), what is considered noteworthy in the provision of facilities include: the completeness, cleanliness and neatness of the facilities offered, the condition and function of the facilities to be offered, the ease of using the facilities offered.

\section{Tourist Satisfaction}

The word satisfaction (Satisfaction) comes from the Latin "satis" which means pretty good and "facio" which means to do or make. Satisfaction can be interpreted as "efforts to fulfill something" or "make something adequate" (Tjiptono and Chandra, 2011: 292). According to Umar (2000: 50), the definition of satisfaction is the level of consumer feelings after comparing with expectations. Meanwhile, according to Kotler and Keller (2009) the definition of satisfaction is the result felt by buyers, service users or visitors who experience the performance of a company, service or vehicle in accordance with their expectations. Visitors feel satisfied when their desires are fulfilled, and feel very happy when their expectations are exceeded. Customers, users or visitors who are satisfied, tend to remain loyal and ignore price changes.

Tourism Research Journal, Volume 4 (2), 2020 
Do Facilities Affect Tourists' Satisfaction at Natural Tourist Attraction?

A Case at Tegenungan Waterfall in Bali

\section{Research Methodology}

As pointed out above, this study has two objectives. First, to describe the profile of tourists who visit the natural tourist attraction of Tegenungan waterfall and second is to determine the effect of tourist facilities on tourist satisfaction at the natural attractions of Tegenungan waterfall. To achieve these objectives, a survey was conducted using a set of questionnaire to tourists who visited Tegenungan waterfall. The survey was conducted for one week applying incidental sampling technique.

The participants of this study were tourists who visited Tegenungan waterfall. A set of questionnaire consisting of 28 statements were distributed to visitors for a week. There were 115 copies of questionnaires successfully distributed to the visitors. After sorting them out, 100 questioners were filled out completely and eligible to be analyzed. The instrument in this study was a questionnaire distributed to visitors at the Tegenungan waterfall. Analysis of the data used is descriptive analysis and simple linear regression analysis by using SPSS computer program.

Prior to analyzing the data using a simple linear regression analysis, a classic assumption test was conducted as a prerequisite for a simple linear regression analysis. The test includes normality test, multi-colinearity test and hetero-cedasticity test (Ghozali, 2010: 91). Normality Test aims to test whether the regression model residuals are normally distributed or not. The normality test can be carried out using the Kolmogrov-Smirnov test. If the significance of the Asymp value. Sig. (2-tailed) is greater than 0.05, so the data is normally distributed (Ghozali, 2009: 83).

\section{Result}

\section{Characteristics of Respondents}

The number of valid questionnaires that were further analyzed in this study was 100 respondents, comprising 51 male tourists (52\%) and $49(49 \%)$ who were female. It indicates the gender balance of respondents for this study. However, the nationality of the tourists does not represent the percentage of number of tourist visit to the waterfall. Most of the respondents are Indonesia (49\%), followed by Australian (8\%), English (6\%), France (5\%), Malaysian (4\%), Indian (3\%) and American, Swiss, New Zealanders, Dutch is $2 \%$ each. The rest of the respondents belong to Poland, Philippines, Canada, Ireland, Hong Kong, Ecuador, China, Africa, Nederland, Japan, Chile, Germany, Belgium, Korea, and Greek (1\% each).

From the results of the study 100 tourist respondents at the Tegenungan waterfall aged $<20$ years totaling 16 people $(16 \%)$, aged $21-30$ totaling 46 people $(46 \%)$, aged $31-40$ totaling 32 people $(32 \%)$, aged $41-50$ totaled $4(4 \%)$ and those aged $>50$ years amounted to $2(2 \%)$. The following is a table of characteristics of age-based tourists:

Tourism Research Journal, Volume 4 (2), 2020 
Do Facilities Affect Tourists' Satisfaction at Natural Tourist Attraction?

A Case at Tegenungan Waterfall in Bali

From the results of the study 100 respondents there were $53 \%$ of tourists who work as private employees, as students $25 \%$, tourists who have jobs that are not on the questionnaire by $13 \%$, as entrepreneurs $6 \%$, as public servants $3 \%$. Based on the data above, tourists who work as private employees are more dominant compared to other jobs.

\section{Validity}

Validity test is a measure that shows the validity of an instrument. According to Sugiyono (2016: 177) validity shows the degree of accuracy between the data that actually occurs on the object with data collected by researchers to find the validity of an item and correlate the score of items with the total of these items. In Sugiyono's opinion, the calculated $r$ value below 0.3 is not yet valid, the value is declared valid if it has a total $r$ value above 0.3. Following are the results of the validity test on each instrument and the variables distributed to 30 respondents:

To describe the research variables, the average value of each indicator in each variable is grouped into 5 categories using Likert scale range (Sugiyono, 2017: 261). To determine the scale range using the formula: RS = (highest valuesmallest value)/class interval.

$\mathrm{RS}=(5-1) / 5=0.80$

From these calculations, the range of scales can be made as follows:

$1.00-1.80=$ Very Dissatisfied

$1.81-2.60=$ Dissatisfied

$2.61-3.40=$ Quite Satisfied

$3.41-4.20=$ Satisfied

$4.21-5.00=$ Very Satisfied

The following is a descriptive analysis of respondents' responses to variable $\mathrm{X}$ (Tourism Facilities) in the table below:

Table 1. Respondents Response to Variable X (Tourism Facilities)

\begin{tabular}{|c|c|c|c|c|c|c|c|}
\hline Indicators & $\begin{array}{l}\mathrm{VD} \\
(1)\end{array}$ & $\begin{array}{l}\text { D } \\
\text { (2) }\end{array}$ & $\begin{array}{l}\mathrm{N} \\
(3)\end{array}$ & $\begin{array}{c}\mathrm{S} \\
(4)\end{array}$ & $\begin{array}{l}\mathrm{VS} \\
(5)\end{array}$ & Total & $\begin{array}{c}\text { Aver } \\
\text { age }\end{array}$ \\
\hline \multicolumn{8}{|c|}{ Accommodation } \\
\hline $\begin{array}{l}\text { Direct access to the } \\
\text { accommodation }\end{array}$ & 0 & 1 & 6 & 78 & 15 & 407 & 4,07 \\
\hline The services provided & 0 & 3 & 35 & 50 & 12 & 371 & 3,71 \\
\hline Prices of the accommodation & 0 & 5 & 42 & 41 & 12 & 360 & 3,60 \\
\hline The environment is comfortable & 0 & 2 & 32 & 57 & 9 & 373 & 3,73 \\
\hline \multicolumn{8}{|c|}{ Restaurant \& Bar } \\
\hline Varied menu choices & 0 & 2 & 15 & 62 & 20 & 399 & 3,99 \\
\hline The restaurant Service & 1 & 4 & 36 & 44 & 15 & 368 & 3,68 \\
\hline Restaurant facilities & 1 & 4 & 26 & 49 & 10 & 363 & 3,63 \\
\hline
\end{tabular}

Tourism Research Journal, Volume 4 (2), 2020 
Do Facilities Affect Tourists' Satisfaction at Natural Tourist Attraction?

A Case at Tegenungan Waterfall in Bali

\begin{tabular}{|c|c|c|c|c|c|c|c|}
\hline $\begin{array}{l}\text { Cleanliness of the place and } \\
\text { quality of food/drinks }\end{array}$ & 2 & 2 & 33 & 49 & 14 & 371 & 3,71 \\
\hline \multicolumn{8}{|c|}{ Transport at Destination } \\
\hline Number/types of transportation & 1 & 2 & 11 & 70 & 16 & 398 & 3,98 \\
\hline Transportation to other places & 1 & 5 & 26 & 52 & 16 & 377 & 3,77 \\
\hline Prices offered & 0 & 2 & 44 & 46 & 8 & 360 & 3,60 \\
\hline Services provided & 1 & 3 & 35 & 48 & 13 & 369 & 3,69 \\
\hline \multicolumn{8}{|c|}{ Sport and Activity } \\
\hline Can do many activities & 1 & 0 & 14 & 62 & 23 & 406 & 4,06 \\
\hline It is safe for swimming & 0 & 1 & 35 & 43 & 21 & 384 & 3,84 \\
\hline Visitors get good photos & 0 & 2 & 27 & 55 & 16 & 385 & 3,85 \\
\hline Pancoran pool is comfortable & 1 & 7 & 32 & 47 & 13 & 364 & 3,64 \\
\hline \multicolumn{8}{|c|}{ Other Facilities } \\
\hline There is a money changer & 1 & 3 & 9 & 58 & 29 & 411 & 4,11 \\
\hline Interesting/safe photo location & 0 & 0 & 28 & 45 & 27 & 399 & 3,99 \\
\hline The facilities are clean and safe & 0 & 2 & 33 & 48 & 17 & 380 & 3,80 \\
\hline Gazebo as a place to rest & 0 & 1 & 33 & 47 & 19 & 384 & 3,84 \\
\hline \multicolumn{8}{|c|}{ Small Stalls } \\
\hline Stalls provide a variety of snack & 2 & 1 & 7 & 67 & 23 & 408 & 4,08 \\
\hline Can do foreign exchange & 1 & 1 & 35 & 32 & 31 & 391 & 3,91 \\
\hline There are many diverse souvenirs & 1 & 4 & 21 & 58 & 16 & 384 & 3,84 \\
\hline The price offered is affordable & 0 & 5 & 34 & 44 & 17 & 373 & 3,73 \\
\hline \multicolumn{8}{|c|}{ Other Services } \\
\hline $\begin{array}{l}\text { Employees provide clear } \\
\text { information }\end{array}$ & 0 & 1 & 13 & 63 & 22 & 403 & 4,03 \\
\hline Friendly service by employees & 0 & 1 & 30 & 51 & 18 & 386 & 3,86 \\
\hline $\begin{array}{l}\text { Safe and comfortable } \\
\text { environment }\end{array}$ & 0 & 1 & 34 & 49 & 16 & 380 & 3,8 \\
\hline $\begin{array}{l}\text { Alertness of service by } \\
\text { employees }\end{array}$ & 1 & 2 & 29 & 55 & 13 & 377 & 3,77 \\
\hline
\end{tabular}

Table 1 shows all respondents perception of the facilities at Tegenungan waterfall. The average answer for each component show that the tourists were satisfied with the accommodation units, restaurants, bars and cafes, Transportation in the Activities and Sports, Other Facilities, Shops and Retail, Other Services that exist in the natural attractions of Tegenungan waterfalls in Gianyar Regency.

\section{E. Discussion}

The results of the normality test in this study using SPSS program showed that Asymp. Sig.(2-tailed) higher that $>0.05$ meaning the data was normally 
Do Facilities Affect Tourists' Satisfaction at Natural Tourist Attraction? A Case at Tegenungan Waterfall in Bali

distributed. The similarity test showed that many points spread above and below the number 0 , it can be concluded that there is no similarity in the variance from the residuals of one observation to another or hetero-cedasticity does not occur.

To determine how much influence the independent variable of the tourist facility has on the dependent variable of tourist facility, simple linear regression analysis using the SPSS 25.0 program shows the following results.

Table 2. Simple Linear Regression Analysis

\begin{tabular}{|c|c|c|c|}
\hline \multirow{2}{*}{\multicolumn{2}{|c|}{ Model }} & \multicolumn{2}{|c|}{ Unstandardized Coefficients } \\
\hline & & B & Std. Error \\
\hline \multirow[t]{2}{*}{1} & (Constant) & 5.127 & 1.621 \\
\hline & Tourist facilities & .134 & .015 \\
\hline
\end{tabular}

Based on the above output obtained a value of $5.127(\alpha)$ and a value of $b$ of 0.134. Thus, a simple linear regression equation can be formed as follows: Y $=5.127+0.134 \mathrm{X}$. Values $\mathrm{a}$ and $\mathrm{b}$ in the above equation can be interpreted as follows: The value of $\mathrm{a}=5,127$ means that, if the tourism facility worth 0 units, the tourist satisfaction will worth 5.127 units. The value of $\mathrm{b}=0.134$ indicates that if the tourism facility increases by one unit, tourist satisfaction will increase by 0.134 units.

T-test is used to find out how far the influence of one independent or independent variable (tourist facilities) in explaining the variation of the dependent variable (tourist satisfaction) and is used to determine whether there is an influence of the independent variable on the dependent variable tested at the 0.05 significance level. Testing through $t$ test is to compare $t$ arithmetic with $t$ table at the real level $=0.05$. The $t$ test has a significant effect if the results of the calculation of $t$ arithmetic greater than $t$ table ( $t$ arithmetic $>t$ table) or the probability of error is less than $5 \%(\mathrm{p}<0.5)$. Using the SPSS 25.0 program, the $T$ test result showed the following result:

Table 3. T-Test Result

\begin{tabular}{|c|c|c|}
\hline Model & $\mathrm{t}$ & Sig. \\
\hline (Constant) & 3.162 & .002 \\
\hline Tourist facilities & 8.977 & .000 \\
\hline a. Dependent Variable: Tourist satisfaction \\
\hline
\end{tabular}

Formulating the Variable Hypothesis of Tourism Facilities:

Tourism Research Journal, Volume 4 (2), 2020 
Do Facilities Affect Tourists' Satisfaction at Natural Tourist Attraction? A Case at Tegenungan Waterfall in Bali

$\mathrm{H}_{0}$ : Tourist facilities do not significantly affect tourist satisfaction on the natural tourist attractions of Tegenungan waterfall.

$\mathrm{H}_{\mathrm{a}}$ : Tourism facilities have a significant effect on satisfaction at natural tourist attractions of Tegenungan waterfall.

From the results of statistical calculations using the SPSS 25.0 program listed in the table, the value of $t$ arithmetic for tourist facilities (X) 8,977, the value is greater than t table that is 1,660 then it can be concluded that $\mathrm{H} 0$ is rejected and $\mathrm{Ha}$ is accepted, which means that the Tourism Facility variable has a significant influence on Tourist Satisfaction on the natural attractions of Tegenungan waterfall.

The coefficient of determination test is used to determine tourist facilities' effect on tourist satisfaction in a simple linear regression analysis.

Table 4. Coefficient of Determination

\begin{tabular}{|l|c|r|c|c|}
\hline \multicolumn{5}{|c|}{ Model Summary } \\
\hline Model & $\mathrm{R}$ & R Square & $\begin{array}{c}\text { Adjusted R } \\
\text { Square }\end{array}$ & $\begin{array}{c}\text { Std. Error of the } \\
\text { Estimate }\end{array}$ \\
\hline 1 & $.672^{\mathrm{a}}$ & .451 & .446 & 1.71949 \\
\hline \multicolumn{2}{|l|}{ a. Predictors: (Constant), Tourist Facilities } \\
\hline
\end{tabular}

Based on the discussion above, it can be seen that $\mathrm{r}$ square is 0.451 . This value implies that the effect of tourist facilities $(\mathrm{X})$ on tourist satisfaction $(\mathrm{Y})$ is $45.1 \%$ while $55.9 \%$ tourist satisfaction is influenced by other variables not examined in this study.

As mentioned by Kotler and Keller (2009) that visitors feel satisfied when their desires are fulfilled, and feel very happy when their expectations are exceeded. Customers, users or visitors who are satisfied, tend to remain loyal and do not pay attention to price changes. In this study, $45.1 \%$ of their satisfaction is influenced by the facilities. In order to obtain the tourist loyalty to this natural attraction the quality and quantity of the facilities need to be improved so that they exceed the tourist expectation. They might pay less attention if, for instance, the entrance fee to the attraction is increased as long as the facilities that contribute to their satisfaction are available and in good quality.

\section{F. Conclusion}

This study concluded that there is a direct relationship of tourist facilities to tourist satisfaction. The t-test test results show that $\mathrm{H}_{0}$ is rejected and $\mathrm{H}_{\mathrm{a}}$ is accepted, which means that there is a significant effect of tourist facilities on tourist satisfaction at the natural attractions of Tegenungan waterfall, Bali. Therefore, for tourists who visit this waterfall feel satisfied, one at the crucial factors that need to be considered is the availability and quality of the facilities for tourists. Further study either on tourists' facilities on tourists' satisfaction in

Tourism Research Journal, Volume 4 (2), 2020 
Do Facilities Affect Tourists' Satisfaction at Natural Tourist Attraction? A Case at Tegenungan Waterfall in Bali

these tourist attractions can be conducted to better understand tourists' perspectives toward the natural attraction of Tegenungan waterfall, Bali.

\section{REFERENCES}

Ghozali, I. (2009). Aplikasi Analisis Multivariate dengan Program SPSS. Semarang: UNDIP.

Ghozali, I. (2010). Aplikasi Analisis Multivariate Dengan Program SPSS. Semarang: Universitas Diponegoro.

Hapsari, R., Clemes, M.D., \& Dean, D. (2017). The impact of service quality, customer engagement and selected marketing constructs on airline passenger loyalty. International Journal of Quality and Service Sciences Vol. 9. Issue 12017.

Kiswanto, A. H. (2011). Pengaruh Harga, Lokasi dan Fasilitas Terhadap Keputusan Berkunjung Wisatawan di Objek Wisata Dampo Awang Beach. UNNES: Eprint.

Kotler, Philip., \& Keller, Kevin Lane. (2009). Manajemen Pemasaran. Jakarta: Erlangga.

Mappisammeng, Andi. (2001). Cakrawala Pariwisata. Jakarta: Balai Pustaka.

Sugiyono. (2016). Metode Penelitian Kuantitatif Kualitataif dan Kombinasi Mixed Methods). Bandung: Alfabeta.

Sugiyono. (2017). Metode Penelitian Kuantitatif, Kualitatif, dan R๘D. Bandung: Alfabeta, CV.

Pitana, I G., \& Diarta, I K. S. (2009). Pengantar Ilmu Pariwisata. Yogyakarta: Andi Offset.

Tjiptono, F., \& Chandra, G. (2011). Service Quality \& Satisfaction, EdisiKedua, Yogyakarta: Penerbit ANDI Yogyakarta.

Umar, H. (2000). Riset Pemasaran dan perilaku konsumen, PT. GramediaPustaka Utama dan Jakarta Business Center, Jakarta.

Utama, I P., Suprastayasa, I G.N.A., \& Wiratnaya, I.N. (2011). Pengaruh Kualitas Pelayananterhadap Kepuasan dan Loyalitas Pelanggan Restoran Cepat Saji. Jurnal Kepariwisataan Vol 10. No 2, 2011.

Yoeti, O. A. (2003). Tours and Travel Marketing. Jakarta: Pradnya Paramita.

Tourism Research Journal, Volume 4 (2), 2020 